the Foundling Hospital in London a scheme for utilizing their residential nursery, day nursery and nursery school at Coram Gardens for teaching and research purposes. It was also suggested that a maternity and child welfare centre might be started on the same site. The next development arose when the Central Council for Training in Child Care, concerned with the training of boarding-out officers and house mothers under the Children's Act, found a shortage of senjors who could take up posts of a supervisory character or as tutors in the various education schemes. The Institute of Education of the University of London and the Institute of Child Health therefore decided to put forward a plan for a joint training and research centre at the Foundling Hospital site. This was discussed with representatives of the Home Office, of the Ministry of Health and of the London County Council Public Health and Education Departments. Eventually a scheme was agreed, under which the financing of the teaching side would be undertaken by the Institute of Education and that of the research side shared between this Institute and the Institute of Child Health with the approval of the University of London authorities.

On the training side the first course will begin immediately. Provision has been made for the appointment of a senior tutor and a junior tutor and for visiting lecturers. Dr. Agatha Bowley has been appointed senior lecturer in child care and Miss J. E. Cass as tutor in child care. Members of the teaching staff of both Institutes will take part in the course. Miss Cass has also been appointed honorary educational supervisor to the day nursery on the Foundling Hospital site, so that there may be general co-operation with the staff in relation to the training of probationers for the National Nursery Certificate. On the research side, provision has been made for two educational research assistants, for a part-time medical assistant and for part-time assistance from the Child Guidance Clinic at the Hospital for Sick Children, Great Ormond Street. Plans for a pilot survey are well advanced. In addition to detailed observations on children in the nurseries and nursery schools, it is planned to extend the investigation to babies in the same area who are not attending such institutions. In this way one of the objects of the research programme is to attempt to assess the educational values or disadvantages of the nursery or nursery school. Those concerned with the planning are endeavouring to take a long view, hoping to follow children through the nursery school to the primary school period and even eventually to adolescence in the youth centre activities in the Harmsworth Memorial Playground, also on the site of the original Foundling Hospital.

\section{Effect the Severe Winter of 1946-47 on Bird Life}

N. F. TrCereurst and P. H. T. Hartley (British Birds, 41, No. (dw November 1948) have examined 121 repurts on the effects of the hard weather of early 94 ti on bird life. February 1947 was the coldesfot month in Britain since 1895, and, in some pafts of the country, temperatures were lower than any noted since records were begun in 1815. Many species of birds were greatly reduced in numbers; but one of the striking features of the collated reports is the lack of any consistency in the proportionate reduction of numbers of groups of allied or ecologically similar species. For example, in the Wirral peninsula tree-creepers were scarcely affected, though nuthatches were much reduced; but on the Surrey-Sussex border tree-creepers suffered heavily and nuthatches not at all. In south-west Devon and in Cardigan, blackbirds suffered heavier reduction than song-thrushes; in the rest of the country blackbirds fared much better than song-thrushes. The diminutions of the stocks of the various species over the country as a whole shows few consistent trends, and probably the only general statements which can be made are that some specimens of most of the winter residents of Britain were found dead, there were relatively few reports of icing of plumage or feet-a cause of mortality frequently recorded in 1939-40-and that there were many reports of unusual shifts of birds in search of food.

\section{Bulletin of the Botanical Society of Bengal 3 p}

AT the hands of shorars of the new Dominion, Indian botany may fonfy be said to be on its way and making god doprogress on a wide front. This is apparent frpma survey of the contents of recent journalo. Whie second volume of the new Bulletin of the Bpharical Society of Bengal (April 1948) contains pupis on cytology, genetics, comparative and devel pmental morphology, mycology and physiology. Thus the aim of the Bulletin, to publish original researches, is being fulfilled. This aim is in no sense marred by the fact that in this, as in other Indian botanical journals, plants of economic importance are often selected for special study; on the contrary, the indigenous and introduced crops, in their many aspects, afford materials of remarkable interest for the investigator; for example, mangoes and bananas among tropical fruits, rice among cereals, and jute among textiles. Papers relating to these crops appear in the current number, while a review of the Bignoniacem of India and Burma serves to remind us of the floristic wealth of this great sub-continent.

\section{Advisory Committee on Medical Nomenclature and Statistico}

THe Registrar General announces that his Advisory Committeg on Medical Nomenclature and Statistics, the function of which is to consider from the medical point of view and to advise upon questions affecting tho International Statistical Classification of Diseases, Injuries and Causes of Death, and any other matters concerning medical nomenclature or statistics which may be referred to the Committee, is constituted as follows: Sir Ernest Rock Carling (chairman); Sir Allen Daley, chairman of the Council of the Society of Medical Officers of Health; medical officer of health and school medical officer, London County Council ; Prof. Ernest Finch, emeritus professor of surgery, University of Sheffield ; Dr. F. H. K. Green, assistant secretary, Medical Research Council; Dr. C. F. Harris, dean of the Medical College, St. Bartholomew's Hospital ; Prof. A. Bradford Hill, professor of medical statistics, University of London; Prof. A. J. Lewis, professor of psychiatry, University of London; Dr. A. Massey, chief medical officer, Ministry of National Insurance; Dr. P. L. McKinlay, superintendent of statistics, General Registry Office, Edinburgh ; Prof. N. C. W. Nixon, professor of obstetrics and gynæcology, University of London; Dr. W. N. Pickles, medical officer of health, Aysgarth, Yorkshire; Dr. A. H. T. Robb-Smith, Nuffield reader in pathology, University of Oxford; Dr. Percy Stocks, chief medical statistician, General Register Office; Prof. R. E. Tunbridge, professor of medicine, University of Leeds; Sir Lionel Whitby, regius professor of physic, Department of Medicine, Univ- 
rsity of Cambridge ; Miss A. L. Winner, medica] ffficer, Ministry of Health. The secretary of the Committee is Mr. L. M. Feery, General Register Office, Somerset House, London, W.C.2.

\section{Seventh Pacific Science Congress: Royal Society Delegates}

THE Royal Society has appointed a delegation of six of its Fellows to attend the Seventh Pacific Science Congress to be held at Auckland and Christchurch, New Zealand, during February 2-22. The programme of the Congress will provide for contributions and discussions on scientific topics of special significance to the Pacific area, and of importance for the welfare of Pacific peoples. Problems depending for their solution on co-operative studies by two or more sciences will be presented for discussion in symposia. Public lectures will be given, and local excursions will be made to places of scientific interest near Auckland and Christchurch. The delegates are: Dr. G. E. R. Deacon, of the "Discovery" Committee, Colonial Office, and the Royal Naval Scientific Service (also representing the Admiralty); Sir Norman Haworth, professor of chemistry and director of the Department of Chemistry in the University of Birmingham since 1925 until retiring last October; Prof. H. D. Kay, research professor of biochemistry, University of Reading, and director, National Institute for Research in Dairying, University of Reading; Prof. G. W. Robinson, professor of agricultural chemistry, University College of North Wales, Bangor ; Sir Geoffrey Taylor, Yarrow research tprofessor of the Royal Society; Prof. C. M. Yonge, regius professor of zoology, University of Glasgow. At the invitation of the Vice-Chancellor of the Australian National University, Canberra, Sir Norman Haworth and Sir Geoffrey Taylor will spend some time in Australia visiting university laboratories before they return to Great Britain.

\section{University Grants Committee}

THE term of office of a number of members of the University Grants Committee is about to expire and the committee has been reconstituted with the following membership: Sir Walter Moberly (chairman), Dr. A. E. Trueman (deputy chairman), Prof. E. D. Adrian, Sir Charles Darwin, Miss D. Dymond, Mr. H. L. Elvin, Mr. E. James, Mr. H. S. Magnay, Prof. W. R. Niblett, Prof. P. S. Noble, Prof. D. Hughes Parry, Prof. G. W. Pickering, Prof. E. K. Rideal, Prof. H. G. Sanders, Prof. J. C. Spence, Sir Alexander Murray Stephen, Mr. B. H. Sumner and Miss Barbara Wootton.

\section{University of Leeds}

THE following appointments have been made in the University of Leeds : Dr. R. D. Preston (senior lecturer in botany), as reader in plant biophysics; Dr. R. Brown (senior lecturer in plant biochemistry), as reader in plant physiology; Dr. T. D. Day, as senior research fellow in experimental pathology and cancer research; Mr. G. C. Easty, as Brotherton research fellow in physical chemistry in the Department of Colour Chemistry.

The University has recently received the following gifts, among others : two research scholarships, each of the value of $£ 325$ a year, plus an allowance of $£ 50$ for apparatus, from the Coal Tar Research Association; from Imperial Chemical Industries, Ltd., $£ 200$ towards the cost of equipping a laboratory in the Colour Chemistry and Dyeing Department, £200 for research in the Department of Biomolecular Structure, and explosives and detonators for the Mining Department ; an electric gyroscope presented to the Mathematics Department by the Sperry Gyroscope Co., Ltd.

\section{The Night Sky in January}

Full moon occurs on Jan. 14d. 21h. 59m., U.T., and new moon on Jan. 29d. 02h. 42m. The following conjunctions with the moon take place: Jan. 17d. 15h., Saturn $3^{\circ}$ S.; Jan. 27d. 06h., Jupiter $5^{\circ}$ N. ; Jan. 27d. 08h., Venus $5^{\circ} \mathrm{N}$. In addition to these conjunctions with the moon, the following conjunctions with planets occur: Jan. 7d. 18h., Mercury in conjunction with Mars, Mercury $0 \cdot 8^{\circ} \mathrm{S}$.; Jan. 26 d. 08 h., Venus in conjunction with Jupiter, Venus $0.02^{\circ}$ S.; Jan. 27d. 21h., Mercury in conjunction with Mars, Mercury $3 \cdot 6^{\circ}$ N. Mercury attains its greatest easterly elongation on Jan. 18 and sets at 16h. $40 \mathrm{~m}$., 17h. $52 \mathrm{~m}$. and $17 \mathrm{~h} .23 \mathrm{~m}$. on Jan. 1, 15, and 31 respectively, and can be seen for a short time as an evening star. Venus rises at $6 \mathrm{~h} .15 \mathrm{~m} ., 6 \mathrm{~h} .42 \mathrm{~m}$. and $6 \mathrm{~h} .57 \mathrm{~m}$. at the beginning, middle and end of the month respectively, and can be seen shortly before sunrise as a morning star. Mars sets more than an hour after the sun, but is still too close to the sun for favourable observation. Jupiter is in conjunction with the sun on Jan. 1 and rises an hour before sunrise at the end of the month, but is still too close to the sun to be favourably observed. Saturm rises at $20 \mathrm{~h} .56 \mathrm{~m} ., 20 \mathrm{~h}$. and $18 \mathrm{~h} .50 \mathrm{~m}$. on Jan. 1,15 and 31 respectively, stellar magnitude $0 \cdot 8-0 \cdot 5$, and can be observed throughout the night in the constellation of Leo. Occultations of stars brighter than magnitude 6 are as follow: Jan. 10d. 22h. $54 \cdot 2 \mathrm{~m}$., $133 B$. Taur. $(D)$; Jan. 11d. $02 \mathrm{~h}$. 17.3m., 32 Taur. $(D)$; Jan. 12d. 17h. 40.7m., 112 $B$. Auri. $(D) ; D$ refers to disappearance and the latitude of Greenwich is assumed. The earth reaches perihelion on Jan. 3d., when its distance from the sun is about $91,450,000$ miles.

\section{Announcements}

Prof. P. Dangeard, of the University of Bordeaux, and M. Louis Emberger have been elected correspondants for the Section of Botany of the Paris Academy of Sciences, in succession to the late MM. Emile de Wildeman and Ernest Pinoy.

Mr. RoBert BARER, of the Department of Human Anatomy, Oxford, has been appointed Alan Johnston, Lawrence and Moseley Research Fellow of the Royal Society for two years from January 1, 1949, renewable for a further three years. He will continue his work at Oxford on the biological and medical applications of new methods of microscopy, with special reference to the Burch reflecting microscope.

Dr. MAGNUS PXkE, who since the spring of 1946 has been principal scientific officer responsible for nutrition in the Ministry of Food, has been appointed to the research staff of the Distillers Company, Ltd., as deputy manager of the Company's new Yeast Research Outstation at Glenochil, Clackmannanshire.

Mr. H G. Foster, lecturer in the Department of Electrical Engineering, University of Birmingham, has been appointed editor of Electronic Engineering, in succession to Mr. G. Parr, who has become technical director of Messrs. Chapman and Hall, Ltd., publishers. 